\title{
Anti-Inflammatory Effect of Ligularia fischeri, Solidago virga-aurea and Aruncus dioicus Complex Extracts in Raw 264.7 Cells
}

\author{
Dong-Hee Kim, ${ }^{1,2}$ Bong-Jeun $\mathrm{An}^{2}$, Se-Gie Kim³, Tae-Soon Park', Gun-Hye Park² and Jun-Ho Son ${ }^{1}$ * \\ ${ }^{1}$ Daegu Gyeongbuk Institute for Oriental Medicine Industry, Gyeangsan 712-260, Korea \\ ${ }^{2}$ Department of Cosmeceutical Science, Daegu Haany University, Gyeongsan 712-715, Korea \\ ${ }^{3}$ Leejiham Cosmetics Co. Ltd, Gyeongsan 712-715, Korea
}

Received January 19, 2011 /Accepted April 18, 2011

\begin{abstract}
The objective of this study was to evaluate the skin inflammation effects of three herb mixture extracts, Ligularia fischeri, Solidago virga-aurea and Aruncus dioicus, which are from Ullung island in Korea. Regulatory mechanisms of cytokines and nitric oxide (NO) are involved in the immunological activity of Raw 264.7 cells. Tested cells were pretreated with $70 \%$ acetone extracts of Ligularia fischeri, Solidago virga-aurea and Aruncus dioicus (LSA-A) and further cultured for an appropriated time after lipopolyssacharide (LPS) addition. During the entire experimental period, 1, 10, and $100 \mu \mathrm{g} / \mathrm{ml}$ of LSA-A had no cytotoxicity. In these concentrations, LSA-A inhibited the production of NO and prostaglandin

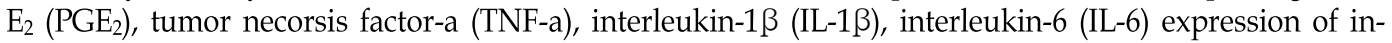
ducible NO synthase (iNOS), and cyclooxygenase-2 (COX-2). LSA-A showed a 60\% $\mathrm{PGE}_{2}$ inhibition rate at $100 \mathrm{\mu g} / \mathrm{ml}$. iNOS and COX-2 inhibition activities were $54 \%$, and $65 \%$ at $100 \mu \mathrm{g} / \mathrm{ml}$, respectively. In addition, LSA-A extract reduced the release of inflammatory cytokines including TNF-a, IL-1 $\beta$ and IL-6. These results suggest that LSA-A may have significant effects on inflammatory factors, and may be a potential anti-inflammatory therapeutic agent.
\end{abstract}

Key words : Anti-inflammatory, cyclooxygenase-2 (COX-2), inducible NO synthase (iNOS), prostaglandin $\mathrm{E}_{2}\left(\mathrm{PGE}_{2}\right)$, Ligularia fischeri, Solidago virga-aurea, Aruncus dioicus

\section{서 론}

염증 반응은 생체나 조직에 물리적 작용이나 화학적 물질, 세균 감염 등의 어떠한 기질적 변화를 가져오는 침습이 가해 질 때 그 손상 부위를 수복 재생하려는 기전이다[21]. 일단 자 극이 가해지면 국소적으로 염증성 성분과 같은 혈관 활성 물 질이 유리되어 혈관 투과성이 증대되면서 염증을 유발하지만 지속적인 염증반응은 도리어 점막손상을 촉진하고, 그 결과 일부에서는 여러 질환을 발생시키는 원인이 된다[25]. 대식세 포는 선천면역뿐만 아니라 획득면역 등 다양한 숙주반응에 관여하여 항상성 유지에 관여하는 것으로 알려져 있으며, 염 증반응 시에는 nitric oxide $(\mathrm{NO})$ 와 cytokine을 생산하여 감염 초기에 생체방어에 중요한 역할을 한다[3]. 포유동물 세포의 nitric oxide synthase (NOS)의 경우, 유사형태가 3가지 존재하 는데 neuronal NOS (nNOS), endothelial NOS (eNOS), 그리 고 inducinle NOS (iNOS)이다. 그 중에서 특히 iNOS가 염증 반응에 관여한다. $\mathrm{nNOS}$ 와 $\mathrm{eNOS}$ 는 항상 발현되어 있으며, iNOS의 경우 interferon- $\gamma$, lipopolysaccharide (LPS), 그리고 여러 가지 염증 사이토카인의 자극이 있을 때 발현된다. 또한 $\mathrm{NO}$ 는 급성, 만성 염증반응을 조절하기도 한다. $\mathrm{PGE}_{2}$ 는 cyclo-

*Corresponding author

Tel : +82-53-810-0320, Fax : +82-53-801-9896

E-mail : bio115@dgom.re.kr oxygenase (COX)에 의해서 arachidonic acid로부터 생산된다. COX에 대해서는 1990년대 초반에 주로 연구되었는데, 이 또 한 유사형태가 2가지 존재한다. COX-1은 거의 모든 조직에 발현되어 있고, prostagrandin을 생산하여 신장의 혈액흐름을 조절하거나 위장의 세포를 보호하는 등의 생리적인 기능을 조절한다. 반대로 COX-2의 경우는 미생물에 의한 감염이나 손상 혹은 여러 요인의 스트레스에 반응한 대식세포 (macrophage)에서 발현된다. 즉 iNOS와 COX-2의 발현과 $\mathrm{NO}$, prostaglandin $\mathrm{E}_{2}\left(\mathrm{PGE}_{2}\right)$ 는 면역세포의 대표적인 염증인 자이다. 또한 염증인자로 염증 사이토카인 (proinflammatory cytokines)인 tumor necrosis factor-a (TNF-a), interleukin-1 $\beta$ (IL-1ß), interleukin-6 (IL-6), monocyte chemoattractant protein-1 (MCP-1) 등이 포함된다[26].

울릉도 지질은 화산암이고 기후는 해양성이어서 식물분포 가 국내의 다른 지역과는 달리 해양식물에서 고산식물에 이르 기까지 다양하며 자생식물이 유명하다. 최근 천연 및 건강 식 품, 기능성 화장품에 대한 사회적 관심 증가와 더불어 자생식 물의 소비가 증가 하고 있으며 이들의 생리활성 검증을 통한 기능성 소재 개발이 필요하다. 곰취(Ligularia fischert)는 취나 물의 일종으로 습하고 그늘진 곳과 경사진 벌판에서 주로 자 라며 곰취의 어린잎은 향취와 맛이 좋아 나물로 먹고, 뿌리는 타박상, 요통, 진해, 거담, 객혈, 염증 등의 치료에 사용되어 왔으며[5,6], 울릉 미역취(Solidago virga-aurea)는 국화과에 속 
하는 취나물의 일종이며 이뇨, 해열, 진통, 건위, 신장염, 방광 염, 감기, 두통, 황달, 폐렴, 항암 등의 치료제로 쓰인다[9]. 삼나 물(Aruncus dioicus)은 장미과에 속하는 식물로서 해독, 편도선 염, 지혈 및 정력보강에 효과가 있다[11,19]. 따라서 본 연구에 서는 곰취, 미역취, 삼나물을 혼합 추출하여 LPS로 활성된 Raw 264.7 cell에서 항염효과를 나타내는 기전을 연구하였으 며 염증에 관련된 다양한 단백질 발현을 측정하였다.

\section{재료 및 방법}

\section{시료 재료}

본 실험에서 사용한 곰취(Ligularia fischert), 미역취(Solidago virga-aurea), 삼나물(Aruncus dioicus)은 울릉웰빙식품에서 2009년 4, 5월경에서 건조된 잎을 구입하여 실험재료로 사용 하였다.

\section{시료 추출}

시료의 추출은 시료 $300 \mathrm{~g}$ 을 실온에서 24시간 침지하여 상 층액과 침전물을 분리하여 동일한 방법으로 3회 반복 추출하 였다. 추출물은 원심 분리 및 여과, 농축 후 동결건조하여 냉장 실에 보관하면서 본 실험의 시료로 사용하였다.

\section{시약 및 기기}

세포 배양액인 dulbeco's modifide eagle medium (DMEM), fetal bovine serum (FBS), streptomycin penicillin 등의 세포배양용 시약들은 invitrogen (Carlsbad, CA, USA)사 에서 구입하였다. 실험에 사용된 시약 중 sodium dodesyl sulfate (SDS), acrylamide, bis-acrylamide는 Bio-rad사(Hercules, CA, USA)에서 구입하였고, NP-40, protease inhibitor, ripa buffer, griess reagent 등은 Sigma Chemical Co. (St. Louis, $\mathrm{MO}, \mathrm{USA}$ )에서 구입하였다. 실험에 사용된 1차 항체인 $\mathrm{iNOS}$ BD bioscience (Sanjose, CA, USA) COX-2 cayman (Ann arbor, MI, USA), $\beta$-actin과 2차 항체인 anti-rabbit Ig-G horseradish peroxidase (HRP)-conjugated antibody (Santa cruz, $\mathrm{CA}, \mathrm{USA}$ )에서 구입하였다. $\mathrm{PGE}_{2}$, cytokine 측정을 위한 ELISA kit는 R\&D systems Inc. (Minneapolis, MN, USA)에서 구입하였다.

\section{세포배양}

마우스의 대식세포주인 Raw 264.7 cell은 한국세포주은행 (KCLB)에서 분양 받았으며, 세포배양을 위해 $10 \% \mathrm{FBS}$ 과 $1 \%$ penicillin-streptomycin을 포함하는 DMEM 배지를 사용하였 다. 세포는 $37^{\circ} \mathrm{C}, 5 \% \mathrm{CO}_{2}$ 조건에서 배양하였다.

\section{MTT assay에 의한 세포 생존율 측정}

울릉도 자생 식물의 세포에 대한 독성 측정은 MTT 방법으 로 분석하였다. Raw 264.7 cell $5 \times 10^{4}$ cells/ml를 96 well plate
에 분주하고 울릉도 자생 식물 추출물을 농도별 $(0,1,10,100$, $1000 \mu \mathrm{g} / \mathrm{ml}$ )로 24시간 동안 처리하였다. Well당 $20 \mu \mathrm{l}$ 의 MTT 용액을 첨가하여 $37^{\circ} \mathrm{C}, 5 \% \mathrm{CO}_{2}$ incubator에서 4 시간 동안 반 응시킨 후, microplate reader를 이용하여 $540 \mathrm{~nm}$ 에서 흡광도 의 변화를 측정하여 대조군에 대한 세포생존율울 백분율로 표시하였다.

\section{Nitric Oxide 생성량 측정}

$\mathrm{NO}$ 의 농도는 배양액 내의 nitrite 농도를 griess reagent를 이용하여 측정하였다. Raw 264.7 cell은 DMEM배지를 이용하 여 $5 \times 10^{4}$ cells $/ \mathrm{ml}$ 로 조절한 후 12 well plate에 접종하고, $5 \%$ $\mathrm{CO}_{2}$ incubator에서 24시간 전 배양하였다. 세포에 $1 \mathrm{\mu g} / \mathrm{ml}$ 의 LPS를 처리하고 1 시간 뒤에 $1,10,100 \mu \mathrm{g} / \mathrm{ml}$ 의 울릉도 자생추 출물을 처리하여 24시간 배양하였다. 배양액의 상층액을 얻은 후 griess 시약과 반응 시킨 후 ELISA reader로 $540 \mathrm{~nm}$ 에서 흡광도를 측정하여 NO 생성율을 백분율로 표시하였다

\section{Prostaglandin $\mathrm{E}_{2}$, TNF-a, IL-1ß, IL-6 생성량 측정}

세포배양액 내의 PGE, TNF- $a$, IL-13, IL-6 생성량은 ELISA kit를 이용하여 측정하였다. Raw 264.7 cell은 DMEM배지를 이용하여 $5 \times 10^{4} \mathrm{cells} / \mathrm{ml}$ 로 조절한 후 12 well plate에 접종하 고, $5 \% \mathrm{CO}_{2}$ incubator에서 24시간 배양하였다. 세포에 $1 \mu$ $\mathrm{g} / \mathrm{ml}$ 의 LPS를 처리 한 뒤 1 시간 후에 $0,1,10,100 \mathrm{\mu g} / \mathrm{ml}$ 의 울릉도 자생식물 추출물을 처리하여 24 시간 배양하였다. 배양 배지를 취하여 $\mathrm{PGE}_{2}$ 를 측정하였다.

\section{Immunoblotting}

배양이 끝난 세포를 수집하여 PBS (phosphate buffer saline)로 세척한 후 $100 \mu \mathrm{L}$ 의 lysis buffer을 첨가하여 30 분간 lysis 시킨 후 $13,000 \mathrm{rpm}$ 에서 20 분간 원심 분리하여 세포막 성분 등을 제거하였다. 총 $30 \mu \mathrm{g}$ protein을 $10 \%$ SDS-PAGE로 분리하여 이를 PVDF (polyvinylidenedifluoride) membrane 에 $55 \mathrm{~V}$ 로 90 분간 transfer하였다. 그리고 PVDF membrane을 $5 \%$ skim milk에서 1시간 방치한 뒤 primary antibody에서 $4^{\circ} \mathrm{C}$ 에서 overnight하여 준다. 다시 TBST로 세 번 세척한 뒤 secondary antibody를 상온에서 1시간 반응 시킨 뒤 TBST로 세 번 세척한 뒤 ECL kit와 반응시켜 LAS 4000 chemiluinescence detection system (Fuji, Tokyo, Japan)을 이용하 여 현상 및 정량을 하였다.

\section{통계처리}

모든 실험은 3 회 반복하여 측정하였고, 그 결과는 평균값 \pm 표준편차로 나타냈으며 통계적 분석은 SPSS 10.0 프로그램을 이용하여 각 처리구 간의 유의성 $(p<0.05,0.01)$ 검증을 위해 분 산분석(analysis of variance, ANOVA) 후 tukey test로 다중비 교를 실시하였다. 


\section{결과 및 고찰}

\section{Raw 264.7 cell에 대한 독성}

마우스 대식세포인 Raw 264.7 cell에 대한 울릉도 자생식물 의 세포독성을 알아보기 위하여 MTT assay를 수행하였다. 울 릉도 자생식물 추출물을 농도별 $(0,1,10,100,1000 \mu \mathrm{g} / \mathrm{ml})$ 로 24시간 동안 처리한 결과 $100 \mathrm{\mu g} / \mathrm{ml}$ 의 농도까지는 독성이 나 타나지 않았지만, $1000 \mathrm{\mu g} / \mathrm{ml}$ 의 농도에서는 세포의 생존율을 $20 \%$ 감소 시켰다(Fig. 1). 울릉도 자생식물 추출물은 $100 \mu \mathrm{g} /$ $\mathrm{ml}$ 이하의 농도에서는 세포독성이 낮아 세포의 생존율에 영향 을 주지 않는다는 사실을 알 수 있었다. 즉, 울릉도 자생식물 추출물의 항염증 효과가 단순한 세포의 사멸에 의한 세포 염 증성 매개물질의 생성억제가 아니라 울릉도 자생식물 추출물 의 고유한 효과라는 점을 의미한다.

\section{Nitric oxide (NO) 생성억제 효과}

$\mathrm{NO}$ 는 NO합성효소에 의해 l-arginine으로부터 생성되는 무 기 유리체로 면역반응, 세포독성, 신경전달계 및 혈관이완 등 여러 가지 생물학적인 과정에 관여하는 것으로 알려져 있으며 농도에 따라 세포 기능유지에 중요한 작용을 하기도 하고 세 포독성을 일으키기도 한다[14,17]. LPS 자극에 의해 발현된 $\mathrm{iNOS}$ 는 많은 양의 $\mathrm{NO}$ 를 생성하게 되며 이에 의한 세포독성 은 염증반응, 세포의 돌연변이 및 종양발생 등에도 관여하는 것으로 알려져 있다. 염증반응과 관련된 조직 손상에서 $\mathrm{NO}$ 와 $\mathrm{iNOS}$ 의 발현이 증가되어 있음이 보고되어 있다 $[15,18,23]$. 활 성 산소 중 하나이며, 최근 염증 유발에 중요한 역할을 하는 것으로 알려진 $\mathrm{NO}$ 생성에 대한 울릉도 자생식물 추출물 효과 를 알아보았다. 생성된 $\mathrm{NO}$ 양을 griess 시약을 이용하여 세포

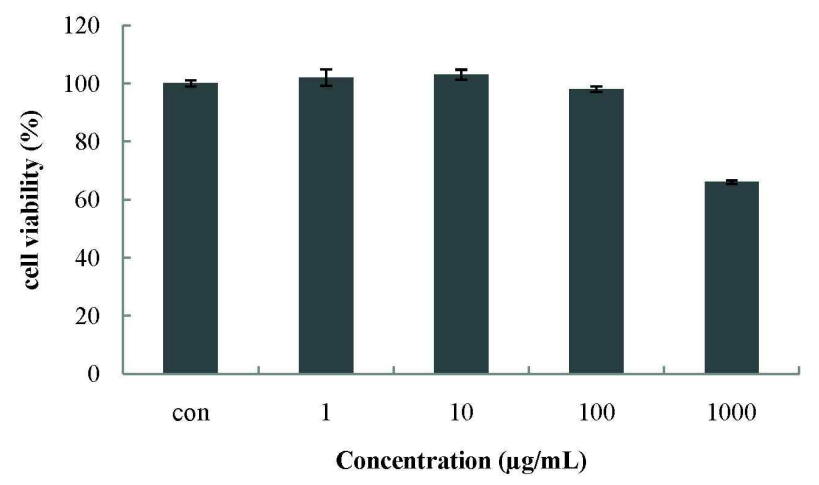

Fig. 1. Cell viability of Ligularia fischeri Solidago virga-aurea and Aruncus dioicus complex extracts on Raw 264.7 cell. Raw 264.7 cells were treated with $1,10,100,1000 \mu \mathrm{g} / \mathrm{ml}$ of LSA-A dissolved in media for $1 \mathrm{hr}$ prior to the addition of LPS $(1 \mu \mathrm{g} / \mathrm{ml})$, and the cells were further incubated for $24 \mathrm{hr}$. Data represent the mean \pm S.D. with eight separate experiments. Data represent the mean \pm S.D. with three separate experiments.
배양액 중에 존재하는 $\mathrm{NO}_{2}{ }^{-}$의 형태로 측정하였다. 그 결과 Raw 264.7 cell에 LPS를 처리한 후 울릉도 자생식물 추출물을 처리한 NO 생성량의 변화는 Fig. 2에 나타내었다. LPS 처리 후 NO 생성량은 정상세포에 비하여 약 4 배 이상 증가되었다. 울릉도 자생 식물 추출물을 $1 \mathrm{\mu g} / \mathrm{ml}$ 의 농도로 처리한 군에서 는 LPS로 증가된 NO 생성량이 LPS 처리군에 비하여 큰 차이 가 없었으나 $10 \mathrm{\mu g} / \mathrm{ml}$ 의 $20 \%$ 이상의 감소율을 나타내었으며, $100 \mathrm{\mu g} / \mathrm{ml}$ 의 농도에서는 $60 \%$ 이상의 $\mathrm{NO}$ 생성 저해를 일으키 는 것을 확인 할 수 있었다.

\section{$\mathrm{PGE}_{2}$ 생성 억제 효과}

LPS로 유도 되어진 Raw 264.7 cell의 monocyte에서 pro-inflammatory cytokine들을 증가시키는 것으로 알려져 있다 [2,24]. 또한 이러한 염증매개 물질의 형성은 phospholipase $\mathrm{A} 2$ 의 활성으로 인해 arachidonic acid가 prostaglandin으로 바뀌는 과정 및 $\mathrm{NO}$ 형성 과정으로 이어지게 된다[17]. 체내 염증과정에서는 과량의 $\mathrm{NO}$ 및 $\mathrm{PGE}_{2}$ 등의 염증인자가 $\mathrm{iNOS}$ 및 $\mathrm{COX}-2$ 에 의해 형성된다. 이 중 $\mathrm{PGE}_{2}$ 는 염증반응, 면역반 응, 그리고 angiogenesis를 촉진하는 등 암 발생에도 깊이 관여 하고 있는 것으로 알려져 있다[3,7]. Raw 264.7 세포에서 염증 성 $\mathrm{PGE}_{2}$ 억제효과를 ELISA kit로 측정하였다. Raw 264.7 세포 에 LPS $(1 \mu \mathrm{gg} / \mathrm{ml})$ 를 처리하여 $\mathrm{PGE}_{2}$ 의 생성을 유도한 후 울릉 도 자생식물 추출물 $1,10,100 \mu \mathrm{g} / \mathrm{ml}$ 농도로 처리하여 $\mathrm{PGE}_{2}$ 생성억제를 측정한 결과 Fig. 3 과 같이 $10 \mathrm{\mu g} / \mathrm{ml}$ 의 농도에서 $20 \%, 100 \mu \mathrm{g} / \mathrm{ml}$ 의 농도에서 $60 \%$ 에 가까운 높은 억제 효과를 나타내었다. 이는 울릉도 자생식물 추출물이 LPS에 의해 발현 되는 $\mathrm{PGE}_{2}$ 생성을 농도 의존적으로 억제 시켜준다는 것을 의

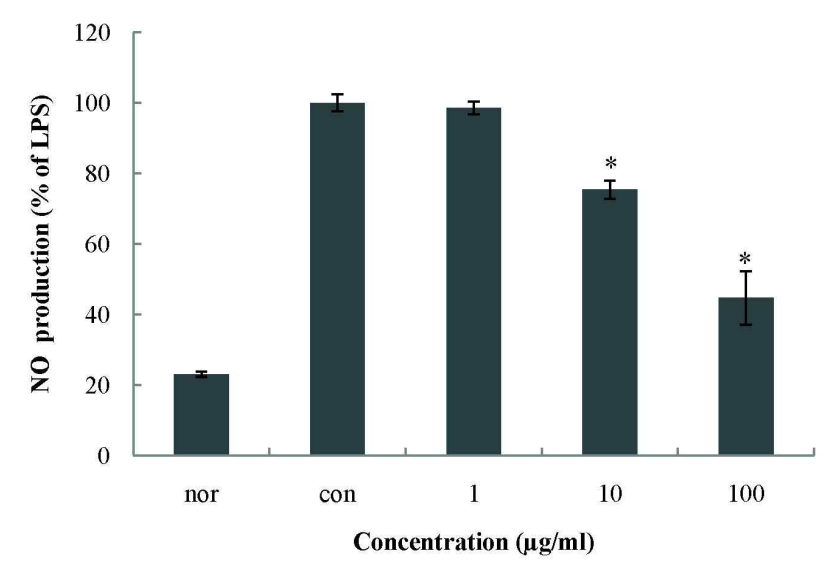

Fig. 2. Inhibitory effects of Ligularia fischeri Solidago virga-aurea and Aruncus dioicus complex extracts on the production of nitiric oxide Raw 264.7 cells. Raw 264.7 cells were cultured with LPS $(1 \mu \mathrm{g} / \mathrm{ml})$ in the presence or absence of LSA-A for $24 \mathrm{hr}$ to determine the level of NO. nor: LPS not induced group, con: LPS induced group. The data represent the mean $\pm \mathrm{SD}$ of three separate experiments (significant as compared to control. ${ }^{*} p<0.05$ ). 


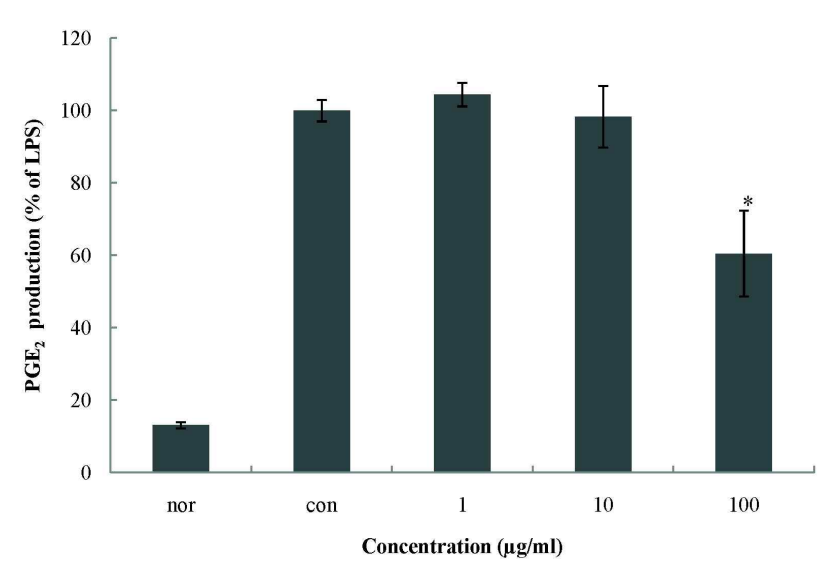

Fig. 3. Inhibition of LPS-induced $\mathrm{PGE}_{2}$ production by Ligularia fischeri Solidago virga-aurea and Aruncus dioicus complex extracts on Raw 264.7 cell. Raw 264.7 cells were cultured with LPS $(1 \mathrm{\mu g} / \mathrm{ml})$ in the presence or absence of LSA-A for $24 \mathrm{hr}$ to determine the level of $\mathrm{PGE}_{2}$. nor: LPS not induced group, con: LPS induced group. The data represent the mean $\pm \mathrm{SD}$ of three separate experiments (significant as compared to control. * $p<0.05$ ).

미한다.

\section{TNF- $a,\|L-1 \beta\| L-$,6 생성 억제 효과}

염증 관련 cytokine 중, IL-1 3 는 monocyte, macrophage, B-cell, dendritic cell, 간세포 등에서 분비되며, TNF- $a$, IL-6와 함께 pro-inflammatory cytokine으로서 여러 면역학적 작용들 과 연관되어 있다. 특히, TNF- $a$ 는 염증반응에 있어서 중요한 역할을 하며 macrophage와 mast cell 등에서 분비되며, LPS반 응의 주요 매개체로서 내재면역에 있어서도 중요한 역할을 하며 만성 염증서 반응과도 관련되어 있다[10]. IL-1 $\beta$ 는 T-cell 의 활성화, B-cell의 성숙, NK cell의 activity를 활성화 하며, IL-6는 림프구를 활성화시켜 항체생산을 증가시키는 것으로,
IL-6의 level은 염증성 병변에서 항상 증가하는 것으로 보고되 고 있다[1]. 본 실험에서 LPS는 TNF- a, IL-1B, IL-6의 생성을 증가 시켰지만 울릉도 자생 식물 추출물을 농도별로 처리한 결과 TNF- $a$ 는 $60 \%$ 생성 억제를 IL- $13, \mathrm{IL}-6$ 는 각각 $50 \mu \mathrm{g} / \mathrm{ml}$ 의 농도에서 $50 \%, 55 \%$ 의 생성 억제 효과를 나타내었다(Fig. 4). 일반적으로 LPS는 macrophage에 작용하여, TNF-a, IL-1B, IL-6의 생성 분비를 촉진시켜 염증반응을 유도하지만, 울릉도 자생식물 추출물은 이 세가지의 cytokine을 유의성 있게 억제 하였으므로 염증성 질환의 치료에 유의할 것으로 생각 되어 진다.

\section{iNOS, COX-2의 단백질 발현 저해 효과}

iNOS는 평소에는 세포 내에 존재하지 않으나 일단 유도되 면 장시간 동안 다량의 $\mathrm{NO}$ 를 생성하며, 생성된 $\mathrm{NO}$ 는 혈관 투과성, 부종 등의 염증 반응을 촉진 시킬 뿐만 아니라 염증매 개체의 생합성을 촉진하여 염증을 심화시키는 것으로 알려져 있다[8,20]. COX는 cyclooxygenase와 peroxidase 활성을 모두 가지고 있는 효소이다. Cyclooxygenase 기능으로서 arachidonic acid를 prostagland로 변환하고, peroxidase기능으로 서는 endoperoxide를 prostaglandin로 변환시키며, prostaglanin는 prostaglandins, thromboxane 및 prostacyclins의 전 구체로 사용된다. COX-1은 모든 세포에 존재하면서, 정상세 포의 항상성을 유지하며, COX-2는 급성염증반응에서 prostagladins의 합성에 관여하고, LPS 및 cytokine에 의해 발현이 유도된다[4,12]. 울릉도 자생식물 추출물에 의한 $\mathrm{NO}$ 생성 저 해 기전을 확인하기 위해 western blot을 실시하여 iNOS의 단백질 발현을 측정하였으며, $\mathrm{PGE}_{2}$ 의 형성 저해 기전을 확인 하기 위해 western blot을 이용하여 COX-2의 발현을 측정하였 다. 그 결과 LPS에 의해 증가된 iNOS와 COX-2의 단백질 발현 양이 농도 의존적으로 유의성 있게 감소되며, $\beta$-actin의 band density 비율에 따라 iNOS 단백질 생성을 $60 \%$ 와 COX-2의 (a)

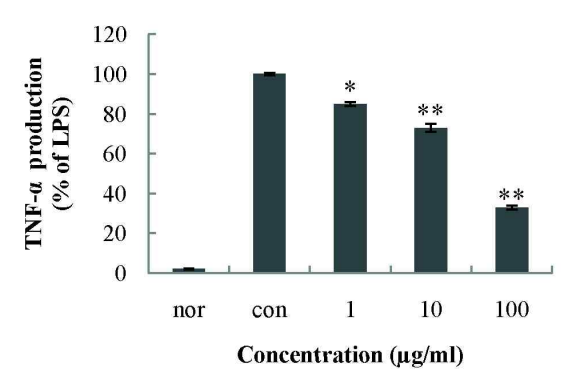

(b)

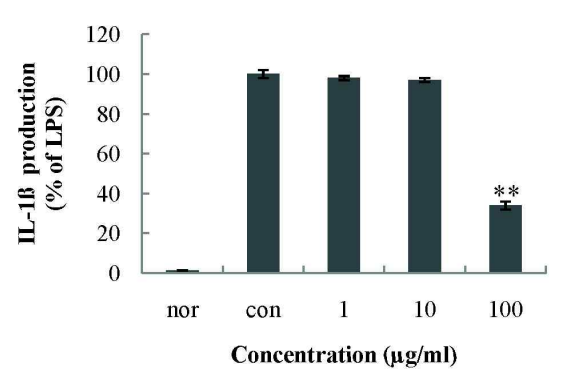

(c)

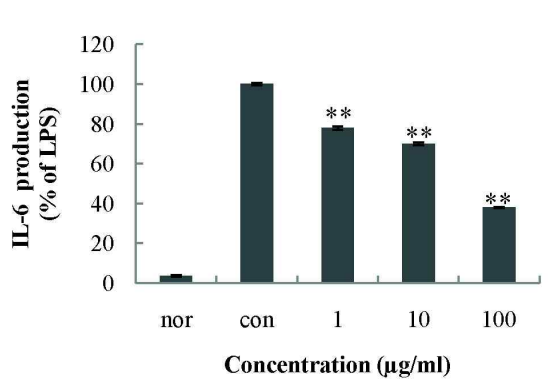

Fig. 4. Effect of Ligularia fischeri Solidago virga-aurea and Aruncus dioicus complex extracts on the production of cytokines stimulated by LPS. Production of TNF-a (a), IL-1 $\beta$ (b), IL-6 (c) were measured in the medium of Raw 264.7 cells cultured with LPS $(1 \mathrm{\mu g} / \mathrm{ml})$ in the presence or absence of LSA-A for $24 \mathrm{hr}$. The amount of TNF-a was measured by immunoassay as described in materials and methods. nor: LPS not induced group, con: LPS induced group. Data represent the mean \pm S.D. with three separate experiments. One-way ANOVA was used for comparisons of multiple group means followed by t-test (significant as compared to control. ${ }^{*} p<0.05,{ }^{* *} p<0.01$ ). 

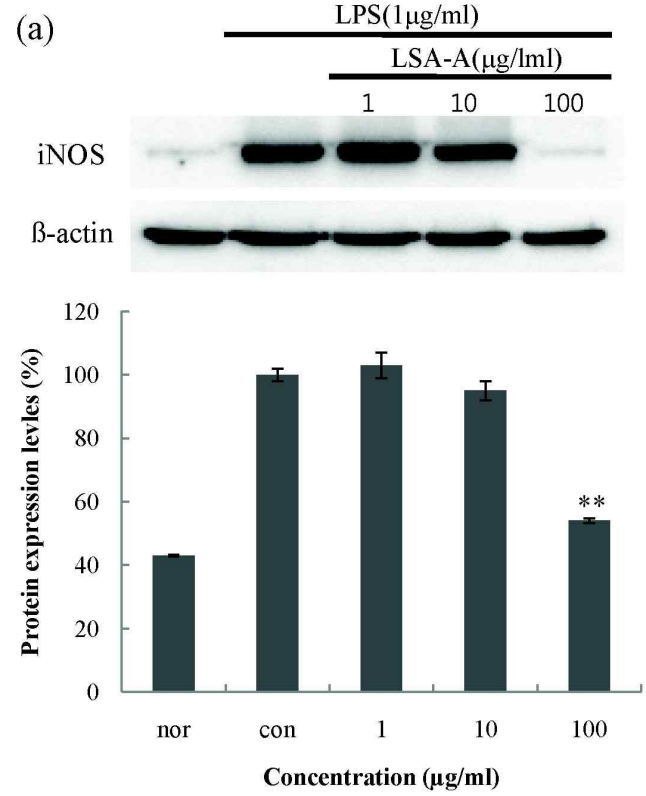
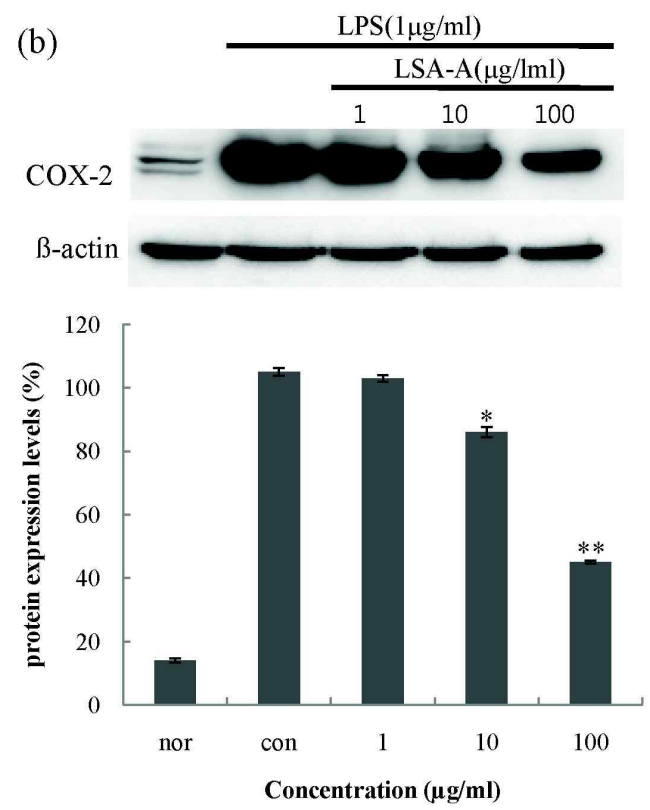

Fig. 5. Inhibitory effects of Ligularia fischeri Solidago virga-aurea and Aruncus dioicus complex extracts on the protein levels of iNOS and COX-2 in Raw 264.7 cells. Raw 264.7 cells $\left(1 \times 10^{6}\right.$ cells $\left./ \mathrm{ml}\right)$ were pre-incubated for $24 \mathrm{hr}$, and the cells were sitmulated with lipopolysaccharide $(1 \mu \mathrm{g} / \mathrm{ml})$ in the presence of complex extracts sample $(1,10,100 \mu \mathrm{g} / \mathrm{ml})$ for $24 \mathrm{hr}$. nor: LPS not induced group, con: LPS induced group. Data represent the mean \pm S.D. with three separate experiments. One-way ANOVA was used for comparisons of multiple group means followed by t-test (significant as compared to control. ${ }^{*}<<0.05,{ }^{* *} p<0.01$ ).

단백질 발현을 $60 \%$ 저해함을 확인 하였다(Fig. 5). 이를 통해 울릉도 자생식물 추출물은 $\mathrm{iNOS}$ 를 저해함으로써 $\mathrm{NO}$ 생성을 저해함을 알 수 있었으며 $\mathrm{PGE}_{2}$ 의 합성 억제를 나타내는 것은 COX-2의 활성 저해에 의한 것임을 알 수 있었다.

\section{References}

1. Delgado, A. V., A. T. McManus, and J. P. Chambers. 2003. Production of tumor necrosis factor-alpha, interleukin 1-beta, interleukin 2, and interleukin 6 by rat leukocyte subpopulations after exposure to substance P. Neuro. 37, 355-361.

2. Funk, C. D., Frunk, L. B., Kennedy, M. E., A. S. Pong, and G. A. Fitzgerald. 1991. Human platelet/erythroleukemia cell prostaglandin $\mathrm{G} / \mathrm{H}$ synthase: cDNA cloning, expression, and gene chromosomal assignment. FASEB J. 5, 2304-2312.

3. Higuchi, M., N. Hisgahi, H. Taki, and T. Osawa. 1990. Cytolytic mechanisms of activated macrophages. Tumor necrosis factor and L-arginine-dependent mechanisms act synergistically as the major cytolytic mechanisms of activated macrophages. J. Immunol. 144, 1425-1431.

4. Hume, D. A., C. A. Wells, and T. Ravasi. 2007. Transcriptional regulatory networks in macrophages. Novartis Found Symp. 281, 2-18.

5. Hwang, B. Y., J. H. Lee, T. H. Koo, H. S. Kim, Y. S. Hong, J. S. Ro, K. S. Lee, and J. J. Lee. 2002. Furanoligularenone, an eremophilane form Ligularia fischeri, inhibits the LPS-induced production of nitric oxide and prostaglandin E2 in macrophage Raw264.7. Planta Med 68, 101-105.

6. Kim, K. S. 2003. Inhibitory mechanism of a NF-kB (furanoligularenone) from ligularia fischeri. Master thesis. Chungnam national university. Taejon, Korea.

7. Kim, J. Y., K. S. Jung, and H. G. Jeong. 2004. Suppressive effects of the kahweol and cafestol on cyclooxygenase-2 expression in macrophages. FEBS Lett. 569, 321-326.

8. Kim, R. G., K. M. Shin, S. K., Chun, S. Y. Ji, S. H. Seo, H. J. Park, J. W. Choi, and K. T. Lee. 2002. In vitro antiinflammatory activity of the essential oil from ligularia fischeri var. spiciformis in murine macrophage RAW 264.7 cells. Yakhak Hoeji. 46, 343-347.

9. Kim, T. J. 1997. Flower growing in the wild flower of Korean, pp. 38, Kunkil media. Seoul, Korea.

10. Lee, A. K., S. H. Sung, Y. C. Kim, and S. G. Kim. 2003. Inhibition of lipopolysaccharide-inducible nitric oxide synthase, TNF- $a$ and COX-2 expression by sauchinone effects on I- $\mathrm{kBa}$ phosphorylation, C/EBP and AP-1 activation. British J. Pharmacol. 139, 11-20.

11. Lee, C. B. 2003. Coloured flora of Korea, pp. 515-516, Hyangmoonsa, Seoul.

12. Lin, W. J. and W. C. Yeh. 2005. Implication of Toll-like receptor and tumor necrosis factor alpha signaling in septic shock. Shock 24, 206-9.

13. McDaniel, M. L., G. Kwon, J. R. Hill, C. A. Marshall, and J. A. Corbett. 1996. Cytokines and nitric oxide in islet inflammation and diabetes. P. Soc. Exp. Biol. Med 211, 24-32.

14. Moncada, S., R. M. Palmer, and E. A. Higgs. 1991. Nitric oxide: physiology, pathophysiology, and pharmacology. 
Pharmacol. Rev. 43, 109-142.

15. Mori, M. 2007. Regulation of nitric oxide synthesis and apoptosis by arginase and arginine recycling. J. Nutr. 137, 1616-1620.

16. Nathan, C. 1992. Nitric oxide as a secretory product of mammalian cells. FASEB J. 6, 3051-3064.

17. Nathan, C. and Q. W. Xie. 1994. Nitric oxide synthases: roles, tolls and controls. Cell 78, 915-918.

18. Palmer, R. M., D. S. Ashton, and S. Moncada. 1988. Vascular endothelial cells synthesize nitric oxide from L-arginine. Nature 333, 664-666.

19. Shin, J. W., S. I. Lee, M. H. Woo, and S. D. Kim. 2008. Effect of ethanol extracts of goat's beard on streptoxotocin induced diabetic symptoms and oxidative stress in rats. J. East Asian Soc. Dietary Life 18, 939-948.

20. Tezuka, Y., S. Irikawa, T. Kaneko, A. H. Banskota, T. Nagaoka, Q. Xiong, K. Hase, and S. Kadota. 2001. Screening of chinese herbal drug extracts for inhibitory activity on nitric oxide production and identification of an active compound of zanthoxylum bugeanum. J. Ethnopharmacol. 77,
209-217.

21. Tizard, I. R. and R. M. Schubot. 2004. Veterinary immunology: An introduction. W. B. Saunders Company, U.S.

22. Toshio, M., I. Yoshinori, and U. Akira. 1991. Studies on the constituents of solidago virga-aurea L. I. structural elucidation of saponins in the herb. Chem Pharm Bull. 39, 2037-2042.

23. Weisz, A., L. Cicatiello, and H. Esumi. 1996. Regulation of the mouse inducible-type nitric oxide synthase gene promoter by interferon- $\gamma$, bacterial lipopolysaccharide and NG-monomethyl-L-arginine. Biochem J. 316, 209-215.

24. Willeaume, V., V. Kruys, T. Mijatovic, and G. Huez. 1995-1996 Tumor necrosis factor-alpha production induced by viruses and by lipopolysaccharides in macrophages: similarities and differences. J. Inflamm 46, 1-12.

25. Willoughby, D. A. 1975. Human arthritis applied to animal models. Towards a beter therapy. Annals of the rheumatic disease. Ann. Rheum Dis. 34, 471-478.

26. Yun, H. J., S. K. Heo, H. S. Yi, C. H. Kim, B. W. Kim, and S. D. Park. 2008. Anti-inflammatory effect of injinho-tang in RAW264.7 Cells. Korean J. Herbology 23, 169-178.

\section{초록 : 곰취(Ligularia fischer), 미역취(Solidago virga-aurea), 삼나물(Aruncus dioicus) 복합 추출물의 항염증 효과 \\ 김동희 ${ }^{1,2} \cdot$ 안봉전 $^{2} \cdot$ 김세기 ${ }^{3} \cdot$ 박태순 $^{1} \cdot$ 박근혜 $^{2} \cdot$ 손준호 $^{1}$ * \\ ( ${ }^{1}$ 대구경북한방산업진흥원, ${ }^{2}$ 대구한의 대학교 화장품약리학과, ${ }^{3}$ 이·지·함 화장품)}

본 연구에서는 울릉도 특산 약용 작물 추출물이 항염증에 대한 실험연구가 이루어져 있지 않은 것에 착안하여 LPS에 의해 활성화된 대식세포로부터 유도되는 염증반응에 대한 억제효과를 조사하였다. 울릉도 자생 식물인 곰취, 미역취, 삼나물의 세가지 식물 추출물을 이용하여 피부 염증에 대하여 연구를 하였다. 산화질소와 cytokine 의 생산은 면역세포의 대표적인 염증인자이다. 세포는 LPS 처리 후 한 시간 뒤에 곰취, 미역취, 삼나물 $70 \%$ 아세 톤 추출물을 처리를 하였다. 세포 독성이 나타나지 않는 농도인 $1,10,100 \mathrm{ug} / \mathrm{ml}$ 를 사용하였다. 곰취, 미역취, 삼나물 $70 \%$ 아세톤 추출물은 NO, PGE 2 , TNF-a, IL- $1 \beta, \mathrm{IL}-6, \mathrm{iNOS}, \mathrm{COX}-2$ 의 생성을 저해 시켰다. $\mathrm{PGE}_{2}$ 는 100 $\mathrm{ug} / \mathrm{ml}$ 의 농도에서 $60 \%$ 에 가까운 저해율을 나타내었다. iNOS와 COX-2 역시 $100 \mathrm{ug} / \mathrm{ml}$ 의 농도에서 각각 $54 \%$, $65 \%$ 가 저해가 되었다. 게다가 곰취, 미역취, 삼나물 $70 \%$ 아세톤 추출물은 염증성 사이토 카인인 TNF-a, IL- $1 \beta$, IL-6의 생성을 감소 시켰다. 이러한 결과로 곰취, 미역취, 삼나물 추출물은 염증 예방과 치료에 효과적임을 확인 할 수 있었다. 